\title{
Social Reproduction in the Live Stream
}

\author{
Elise D. Thorburn
}

Brock University, St. Catharine’s Ontario, Canada, ethorburn@brocku.ca

\begin{abstract}
In this paper I seek to explicate how alternative, particularly feminist, modes of social reproduction emerge through digital networks in contemporary social movements, using Concordia University Television's live streaming of Quebec's 2012 student strike as a case study. By examining this struggle in the light of more contemporary movements and technological changes. In this I seek to aid an understanding of technology use in social movements that presents itself not simply as a new or alternative political project, but as a new way of collaboratively accounting for collective interests. Sketching the changes since 2012 by looking to the live streaming initiatives in the anti-police brutality protests in Ferguson and Baltimore 2015, this paper will suggest future horizons of digital and embodied activism around social reproduction focused on media forms within social movements. Based on ethnographic research, including participant observation and interviews, I argue that the practices and projects of live streaming can expand forms of social reproduction autonomous from both the state and capital. The digital practices of social reproduction emerging in contemporary struggles can contribute to circumventing power while at the same time constituting sites of resistance within and beyond social and political contestations.
\end{abstract}

Keywords: Digital Media, Social Reproduction, Live Streaming, Social Media, Social Movements

Acknowledgement: This article makes use of interviews with CUTV volunteers and workers, and develops out of my own engagement with the live streaming project of the station. I want to thank all those volunteers and workers who brought the project to fruition through the Spring and Summer of 2012. Especially thanks to Laith Marouf and Gretchen King for their longstanding media activism, and for their continued interrogation into what we can learn from the experience of CUTV and how we can deepen our radical practices as media activists. I also want to thank the reviewers who provided such engaged and thoughtful feedback for this piece. Such careful attention to ideas is an act of solidarity.

\section{Introduction}

In the most recent cycle of struggles - those beginning in 2010 with the wave of resistances across the North Africa and the Arab world, continuing in the plaza occupations in Europe and the Occupy movement in North America - a changed logic of activism is evident (Dyer-Witheford, 2015). Research on these struggles has often emphasised the interactions of the digital (through online forms of activism, communication, and coordination) with the embodied (in assemblies, spatial occupations, and face-to-face encounters [Gerbaudo 2012]). Although gender has been considered in regard to these struggles (Herrera 2014) feminist concerns have been either neglected or - in the squares themselves - met with hostility (Ezquerra 2012). Each of the sites and movements in the post-210 cycle of struggle, though, have placed the practices of what can be considered "social reproduction" at the centre of the movement, even if they are never theorised as such. While key to the emergence and maintenance of the spatial occupations of this most recent cycle of struggles 
(Brown et al. 2013), social reproduction has been under-theorised in much of the literature charting these resistance movements, and its relationship - as embodied practices - to the prevailing digital technologies used in struggle has been almost absent in recent scholarly work.

Social reproduction refers to the capacities of populations to reproduce themselves and through this to reproduce the material basis of the economy (Bezanson and Luxton 2006; Federici 2012). It is a site wherein human beings and capital compete for the reproduction of living bodies, and contemporary social movements have become ground zero for such socially reproductive contestations (Thorburn 2016). Within contemporary movements, struggles over social reproduction are increasingly channelled through digital networks as well as embodied practices. This digitalembodied convergence opens up strengths and weaknesses in the contemporary epoch of social/political contestation.

Over the unfolding of the long neoliberal period, working class power and its capacities for resistance have been significantly destabilised (Dyer-Witheford 2015). As such, human beings have been made globally even more vulnerable to the shifts and swings of an unforgiving market economy, and the capitalist relations of the global South trickle upwards to impact the capitalist relations in the previously stable global North. Today the working class is segmented and uneven across the globe, and the dynamics that their struggles take are equally segmented and uneven. Yet these varied dynamics of struggle carry common threads: they emerge as a response to a crisis of care (Brown et al. 2013) or of social reproduction, and mark attempts by movements to re-assert autonomy from the market in our reproductive capacities, to build our lives and relationships outside of the cash nexus, outside of the imperatives of commodification and securitisation. While communicative technologies, such as social media, have been a key part of channelling socially reproductive labours into accumulative circuits (see Wages for Facebook, for instance) ${ }^{1}$ these technologies have also played an important role in the recuperative attempts at making social reproduction autonomous from both the market and the state.

In this paper I seek to explicate how alternative, particularly feminist, modes of social reproduction emerge through digital networks in contemporary social movements, using Concordia University Television's live streaming of Quebec's 2012 student strike as a case study. By examining this struggle in the light of more contemporary movements and technological changes. In this I seek to aid an understanding of technology use in social movements that presents itself not simply as a new or alternative political project, but as a new way of collaboratively accounting for collective interests. Sketching the changes since 2012 by looking to the live streaming initiatives in the anti-police brutality protests in Ferguson and Baltimore 2015, this paper will suggest future horizons of digital and embodied activism around social reproduction focused on media forms within social movements. Based on ethnographic research, including participant observation and interviews, I argue that the practices and projects of live streaming can expand forms of social reproduction autonomous from both the state and capital. The digital practices of social reproduction emerging in contemporary struggles can contribute to circumventing power while at the same time constituting sites of resistance within and beyond social and political contestations.

This is not to argue that what we are witnessing in current digital-embodied resistant convergences and the focus on social reproduction marks a qualitatively and quantitatively different moment in the history of struggle. Rather, struggles over all

\footnotetext{
${ }^{1}$ Wages for Facebook (http://wagesforfacebook.com/) and also Jung (2014).
} 
those things that permit the reproduction of human beings as subjects antagonistic to capital's domination has been the centrepiece of all resistant movements. In neoliberal capitalism there is something novel, though, in the extend to which our reproductive capacities - particularly those involving communication - have been thrown onto the market and thus forge within us an alienation not only from our labour but also from our most intimate relationships with others, with our lives, leisures, and loves (Thorburn 2016; Andrejevic 2011). This commodification has been facilitated by emergent digital technologies. At the same time, these technologies - often the very same technologies - and their convergences with embodied practices can make a site for the reclamation of our reproductive capacities, broadly defined, in the contemporary moment. When viewed through the framework of feminist social reproduction theory, the digital-embodied nexus of contemporary struggle opens up a variety of future horizons towards which social movements can turn.

Because of the centrality of social reproduction theory to this argument, this paper begins with an examination and definition of the concept. I then chart the main lines of the 2012 Quebec student strike and focus on Concordia University Television's use of live streaming technology to cover the strike from within the very moments of contestation themselves. I examine how recuperative or autonomous attempts at social reproduction flowed through CUTV's live streaming project in three ways: its material composition, its expansion of "participatory journalism," and its immediacy. Finally, I briefly turn to the emergent technologies of live streaming to highlight both some of the limits of social reproduction across new media technologies and to suggest where digital-embodied convergences for recuperated social reproduction may emerge next.

\section{Social Reproduction}

In the fallout of the 2007-8 economic crises, Marxist categories for understanding the globally ascendant system of capitalism moved closer to the mainstream of academic and popular discourse. Generally circumscribed as an on-going relational struggle between waged workers and capitalist owners, this description of capitalism is both materially and theoretically incomplete. At its foundation, capital is a system of social relations engaged in a perpetual process of expansion through formal and real subsumption. As such, how this system and its participants are reproduced on a daily and intergenerational basis becomes an important frame through which to consider processes of accumulation. For Marxist feminists such as Dalla Costa and James (1973) and Federici $(2004,2012)$ social reproduction also became a key framing through which to understand how resistances to capitalism are produced and reproduced.

In Volume II of Capital, Marx (1978) analysed the reproduction of the capitalist system, noting that capital endeavours simultaneously to reproduce human labourpower alongside the conditions of capitalist social relations. In essence, then, for Marx social reproduction is the reproduction of capitalist society. But theorisations of the reproductive component of the capitalist mode of production did not extend, for Marx and many Marxists afterwards, to any sort of detailed analysis, until taken up by Marxist feminist writers around the 1970s. In the Marxist feminist theoretical tradition, social reproduction refers to the labour process that creates value through the production and reproduction of labour power (Vogel 1983). It can include the material means of subsistence such as the provisions of food, water, housing, and health care, or, most frequently associated with Italian feminist theorists, the particular kinds of labour involved in the daily and intergenerational regeneration of others - i.e., domestic, care, affective, and sexual work; labours primarily associated with women 
(Dalla Costa and James 1973; Federici 2004, 2012; Fortunati 2007). In more recent work on theories of social reproduction, the concept has been taken up to consider the struggles over the provisions of the welfare state - those social institutions and infrastructures that reproduce social relations on a grand scale - the school, public education systems, health care, social security, and pension plans (Bezanson and Luxton 2006). Social reproduction is all of those things which enable labour power to go to work another day, and which enable the basic means of existence through which we can create and sustain relationships, whether these relationships are to each other or to capitalism. It is the processes of social reproduction that sustain capitalist drives for accumulation. This feminist focus not only corrects a gender blindness at the core of most theories of the economy and class struggle - including Marxist theories - but suggests an alternative mode of understanding capitalist and anti-capitalist relations that place care-giving at the centre (Bezanson and Luxton 2006; Federici 2012).

The range of writings on social reproduction is broad, and hence coherent and unified theory is difficult to ascertain. In general Marxist theories of social reproduction signify three levels -1 ) the reproduction of individual labour power; 2) the reproduction of the total workforce of a given capitalist social formation; and 3) the reproduction of the capitalist system itself. For the purposes of this argument, I will follow the through line of the Italian Marxist feminists, touching on all three levels but focusing these levels primarily for their potential as sites of resistance to the reproduction of capitalist social relations, rather than the reproduction of them.

In this framework, social reproduction can be understood as the quotidian and intergenerational maintenance and reproduction of life, designating the ways in which the physical, emotional, and mental labour necessary for the production of human populations (and hence labour power) is socially organised. More important to my argument are the affective elements of social reproduction: the support we give, the regenerative activities of love and care we participate in, and the work of "maintaining a sustainable environment, or satisfying emotional needs" (Brown et al. 2013, 78). This is to focus on the web of social relations that maintain and reproduction human labour power as life, and to conceive of this as a site of work that can be, Federici (2012) insists, the "point zero" of revolutionary struggle. As a site of work, social reproduction involves conflict, violence, and exploitation, and becomes a powerful site for contestations because it is the least abstracted form of labour. Because social reproduction simultaneously produces human labour power and human life, relationships to capital and relationships to each other, it is a site of potential antagonism and struggle. In creating labour power social reproduction creates life - we become the subjects we know ourselves to be - friends, lovers, parents, workers, comrades through sets of socially reproductive acts. These processes involve distorted relationships that are central to the reproduction of capitalism as a system of exploitation and domination, but also hold the kernel of its annihilation. Social reproduction creates and recreates labour power, yes, but none of us is reducible simply to our capacity for labour, and herein lies the opening for socially reproductive resistances. Federici (2012) argues that social reproduction holds a "dual character;" it can become a site for revolutionary self-activity and collective co-constitution. Social reproduction reproduces human beings "for capital, for the labour market, as labour power, but it also reproduces our lives and potentially it reproduces our revolt against being reduced to labour power" (Vishmidt 2013). This reproductive labour is fundamental to the continuation of social movements and struggle, and is often forms the ground on which struggle is articulated. Recognising the dual character of social reproduction allows us to determine which labours we can refuse (those that reproduce us for 
capital) and which we must use to foment social movements and struggles for social change.

There is a long history to struggles that make use of socially reproductive tactics in movements - the creation of "communities of care" and collective forms of reproduction that sustain movements have been at least partially present in the contestations of the twentieth century. It was the feminist movements of the mid-twentieth century that asserted that any revolution must begin at home (Haiven 2011). Regardless, reproductive labours of resistance have a similarly long history of reproducing the gendered relations and inequalities of daily life into movement spaces. Such clearly gendered reproductive labour remains in the more contemporary techno-centred movements of today. The division of labour in the 2011 Occupy movement was, for example, present but often ignored. As Boler et al. (2014) note, it was the "connective labour" taking place online that provided some of the space for reproduction in the Occupy encampments, and this labour was largely the domain of women. Connective labour, they note, is networked and affective, taking place online and through social media. It involves the work of administrating, documenting, and connecting via digital portals, and in Boler et al.'s research it was primarily feminized and frequently invisible, or ignored as an aspect of movement building. Very often, labours taking place online are disregarded as aspects of social movement struggle, and socially reproductive labour is thought to only exist in the very embodied interactions we have with each other in physical space.

In the remainder of this article, then, I want to chart some of the ways socially reproductive resistances emerged through the digital technologies used in contemporary expressions of social struggle. In this, I will focus on the affective dimensions of recreating human subjects as sites and actors in moments of resistance. While digital technologies share a problematic role in the commodification and securitization of socially reproductive capacities (Thorburn 2016), they also create new openings and the possibility of newly centred subjects in struggle.

Before moving on to my case study I want to stress my position against a fetishisation of the digital. Technology is a broad term, what Leo Marx called a "hazardous concept" (2010) - it refers not only to specific devices or inventions, but also complex socio-technological systems, such as institutions and organisations, infrastructures and belief systems, the ambiguous, messy and incoherent new formations of the social. Class struggles and social reproduction, then, have always been a merger of the deeply embodied and the highly technical, or what I have elsewhere called a humanmachinic assemblage (Thorburn 2013a). While I am going to focus on the digital components of the strike today, my reading of the contemporary moment relies upon detailed understandings of the embodied aspects of social movements and social reproductions, while remembering that the embodied is always and has always been entangled with the technological.

I also want to note that much of the research for this article grew out of my own participation in the Quebec student strike, and from interviews, participant observation, and document analysis I engaged in during and after the strike. I spoke to organisers in student associations and participants in the strike, community members and student activists from the past, volunteers with CUTV, people active on the streets, long-time activists and newly radicalized students. I read through blog posts, newspaper stories, journal articles, and even diary entries to ascertain the experiences people had of the strike and to draw connections between the theories I was operationalising and the actual on-the-ground moments of struggle. I feel confident that what I present here is a more-or-less accurate reflection of the experiences, lessons, and structures of the Quebec student strike and the livestreaming at CUTV. 


\section{Quebec Student Strike and CUTV}

In 2012 students at universities and colleges across Quebec engaged in a months long general strike, resisting a proposed tuition fee hike - \$325 annually for five years, for a total increase of $\$ 1625$ - which marked state-based politics at the heights of globally ascendant austerity politics. Throughout the seven months of the strike, roving marches marked the nights, economic disruptions marked the days. At its peak, 150,000 were on strike from classes. Demonstrations featuring at least a quarter of a million people celebrated the strike's anniversary each month. Striking students attended daily general assemblies in their departments and faculties, and sent representatives to the monthly assemblies of the province-wide coalition spearheading the strike, CLASSE. ${ }^{2}$

The Quebec student strike differed in form from the other contemporary assembly movements - it was not a spatial occupation and so socially reproductive practices like community kitchens, tent cities, childcare spaces, and care for the homeless were absent. While university classrooms or entrances were briefly blockaded, the strike was more an occupation of social reproduction as lived experience - as education, as affect, and as communication. With its focus on educational institutions, the Quebec student strike highlighted how processes of social reproduction are increasingly channelled through a state infrastructure that is beholden to the demands of the market, and thus fails those it claims to serve. Austerity, then, must be read as the latest iteration of a crisis of social reproduction.

Through both blustery and contemplative moments of the strike, amidst the relative calm of general assemblies and chaos of the street demos, a group of students and media activists undertook a project to revolutionise journalism, the use of technology in social movements, and the technological components of social reproduction. Using the latest in live streaming technology, teams of media activists from Montreal's CUTV (Concordia University Television) took to the streets, marching alongside protestors, filming the demonstrations and instantly live streaming those images to the internet, beaming them to computers across the province, country, and in fact the world. Although the use of digital technology was discouraged as a form of participation in Quebec assemblies, such machinic components did form a key part of the strike in its processes of social reproduction. The stream highlighted the ways affective capacities of social reproduction channels through pathways of communication and how care/solidarity can be transmitted via digital networks.

CUTV is a student- and community-run television station based out of Concordia University in Montreal, Quebec, broadcasting via a closed-circuit TV network, DVD releases, internet distribution networks, and public access TV channels. It is the oldest university television station in Canada, founded in 1969. Undergoing a series of changes from $2009-2010^{3}$, the station emerged into a wider public spotlight with the decision, in the winter of 2012 , to obtain high definition live streaming equipment, and to begin streaming video footage of the demonstrations underway in Montreal and

${ }^{2}$ Coalition large de l'Association por une Solidarité Syndicale Étudiante (CLASSE) was the large student union that represented departments, faculties, and universities across several campuses in Quebec.

${ }^{3}$ In 2009 a referendum at the University saw an increase in the student levy directed towards CUTV (up to 34 cents per student), which effectively doubled the station's budget. This permitted the station to hire staff. Laura Kneale was hired as Station Manager in 2010 and Laith Marouf as Programme Director. 
across the province as part of the Quebec student strike ${ }^{4}$. As a journalistic and social media form, CUTV's live stream project was contributed to the development of autonomous processes of social reproduction. The composition of the live stream teams allowed affective relationships to be created, communicated, and transmitted in both human and machinic forms; the live stream created a digital location for autonomous social reproduction. In this sense, the CUTV's live stream project offers us a concrete example of the role of technology in contemporary movements of socially reproductive resistances.

In the spring of 2012, the station leased equipment from LiveU - the apparatus provider - and purchased platform space from Livestream at livestream.com. LiveU provided CUTV with an LU60 backpack, which contains the technology necessary to stream live video to a web platform. This includes encoding hardware, a Firewall cable, and a built-in wireless connection with six load-balanced $3 G$ modems that deliver data over 3G and 4G cellular networks. The LU60 backpack contains a transmission system that is connected via a lengthy wire to any shoulder-mounted camera. The transmission system takes video images, disassembles them, bonds them, and sends them over cellular networks to the Livestream platform where they are reassembled and uploaded. The backpack also contains its own modem and router, making it a mobile Wi-Fi hotspot, allowing again for constant connectivity but also permitting other mobile devices to connect to the Internet. The transmission system also simultaneously analyses conditions in the field, and recommends the most suitable video settings for the prevailing conditions ${ }^{5}$.

In the winter and spring of 2012 CUTV broadcast live each night from the midst of the demonstrations. The camera and crew were on the ground and in the crowd whether the demonstration was a peaceable (though speedy) walk through Montreal's city streets or in the near war-zone of Victoriaville where teargas canisters and rubber bullets assailed protestors, injuring some and hospitalising others. CUTV's reporters and the live stream team did not remain at a distance from struggle, but were actively a part of it, following and aiding injured demonstrators, and often at-

${ }^{4}$ The demonstrations that crossed Quebec, and reverberated in the rest of Canada in the winter, spring, and summer of 2012 were centred around student opposition to increased tuition fees at Quebec's publicly funded universities. The movement involved almost all university and CEGEP (college) campuses across the province, and was largely lead by a coalition of student associations and individual student unions under the umbrella of CLASSE (Coalition Large de I'ASSE) which operated on the basis of directly democratic decisionmaking through regular general assemblies. Soon garnering vast public support, monthly demonstrations sometimes involved $250,000-400,000$ people including labour activists and community groups, and nightly demonstrations began lasting for several months consecutively. "Casserole" protests also began, inspired by the cacerolazos of Chile in the 1970s, and neighbourhood assemblies also began across the city of Montreal, incorporating community members into the organising and structure of the student strike. The strike had always been, but became clearly then, about much more than simply tuition fees, and instead was a sustained attack on the austerity policies of the Liberal government. With approximately 150,000 students on strike by May of 2012 the Liberal government soon folded, and declared an election which they lost. The fee increases have recently been re-negotiated by the victorious Parti Quebecois government, and will, in the long run, amount to greater increases than what the Liberal party was originally proposing. Therefore, although quiet now, student strikes could easily erupt again in Quebec in the coming months and years. For further writing on the student strike of 2012 see parts 1 and 2 of WI: Journal of Mobile Media, Vol 6, No. 2, Spring 2012.

${ }^{5}$ All information about the LiveU LU60 backpack can be found through the LiveU website at www.liveu.tv 
tacked themselves. In this way, CUTV's live streaming projects established itself not simply as passive, objective, side-lined media, but as collaborator, co-constructing new resistant subjectivities and with them new socially reproductive capacities. CUTV played an important role in the subjective transformations underway in the Quebec student strike.

The remainder of this article will explore these the ways in which socially reproductive capacities were expanded through the live streaming projects of CUTV. I will examine this first through the concept of participatory journalism that was deepened through the live stream project, and second, through the ways in which livestreaming's immediacy becomes a source of resistant socially reproductive capacities. This article will conclude with some thoughts on the ways newer, more mobile live streaming technologies potentially expand or contract such socially reproductive capacities within contemporary social movements.

\section{Participatory Journalism: The Assembly of CUTV and the Recuperation of Social Reproduction}

CUTV's live stream broadcasts greatly differed from most mainstream media footage (and from the live streaming footage of earlier demonstrations and riots) ${ }^{6}$ in that the station broadcast live from the centre of demonstrations, marching alongside the demonstrators, many of whom were their peers. These broadcasts provided activists, strike participants, and the broader community with opportunities for bold, unedited reflections on the struggle by strike participants themselves; self-representation and direct communication with audiences, mediated only through the participatory technologies at hand. Images and stories of strike participants were not channelled through the political yet purportedly "objective" lens of the mainstream media. ${ }^{7}$ For those unable to attend the actions, for those at far remove from Montreal, or for those impeded by mobility issues or familial responsibilities, the live stream gave insight into the motivations, ideas, analysis, and politics of the strikers and demonstrators from their own perspectives. These went far beyond the mainstream media's reliance on government platitudes and shocking images of rioters smashing windows or running from tear-gas happy police. ${ }^{8}$ This was a particular kind of journalism, a movement journalism for the prevailing technological conditions.

The notion of "participatory journalism" is similar to embedded journalism used by more mainstream news organisations in wartime scenarios, ${ }^{9}$ but unlike embedded

\footnotetext{
${ }^{6}$ For example, the live streaming of the Tahrir Square occupation was shot from a high angle, from a camera several hundred feet away and in the air. The same is true of the Greek riots, and the anniversary of the occupation in Egypt in 2012. CUTV, by contrast, placed itself in the very centre of the demonstrations.

${ }^{7}$ For critical analysis of mainstream media's objectivity refer to Herman and Chomsky, 1988. and Herman, 1996.

${ }^{8}$ This image of demonstrators as spoiled children engaged in wanton property destruction was especially prevalent in mainstream English-language media in the rest of Canada. But, while the coverage and analysis was better in French, students were rarely able to see complex, well-rounded descriptions and debates about their struggle.

${ }^{9}$ Embedded journalism refers to news reporters being "embedded within" or attached to and given the protection of military units during armed conflicts. While it has some historical precedents with regards to interactions between journalists and military personnel, it became prevalent with the 2003 invasion of Iraq. Embedded journalism has been critiqued by media professionals themselves for the inherent bias that comes with covering an institution charged with protecting one's life. Critical articles include Cockburn, 2010 and Myers 2010. As well documentaries such as The War You Don't See and War Made Easy: How Presi-
} 
reporters participatory journalists themselves have a stake in the struggles. These are invested media makers, creating new journalistic practices and alternative channels of communication using the power of emergent technologies and social media (Lievrouw 2011). The human component of the CUTV live stream team was largely made up of activists and students on strike or those sympathetic to the strike. Many volunteers were grounded within the student movement or in the broader Montreal anti-authoritarian social justice community (Jeppesen 2012). As CUTV volunteer Jadis Dumas argues, "part of why CUTV was so successful and why it had such a strong presence and longevity was because of the confidence it had already built within the radical community."10 The demographic makeup of the station and the affective networks of CUTV members allowed for the creation of bonds of trust and solidarity between strike participants and the media form. But the demographics also meant that CUTV journalists shared many of the class positions and concerns of striking students, and had inside knowledge of their aims and goals, and the actions of the movement. This departs from the usual separation that occurs between the mediated and the media makers, and as such confirms CUTV as a mode of participatory journalism.

But it is the affective dimensions of the relationship between journalism and participation that ties CUTV to processes of recuperating social reproduction from securitising or commodifying impulses. Dumas elaborated upon this relationship of movements to media:

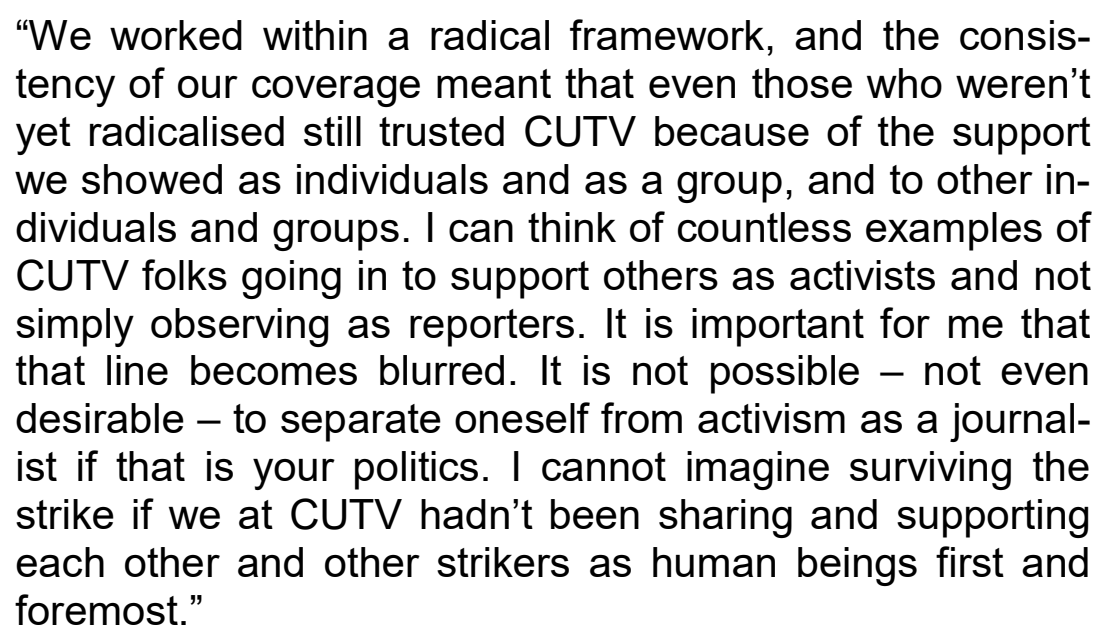

Certainly, the support CUTV enjoyed from the student strikers developed out of the station's participatory role in the struggle and the consistency of their reporting, which created a sphere of autonomous communication. But such an infrastructure of social reproduction was impossible without the specific technology that created the possibility of the live stream as "participatory journalism." The necessity of both the human and technological components of this project were apparent, Laith Marouf notes, because:

We are not just trying to document things with high quality imaging, like some film collectives do, nor just be there when action happens, like some media activists do. We

dents and Pundits Keep Spinning us to Death also take a critical approach to embedded reporting and journalistic bias in mainstream media organisations.

${ }^{10}$ Interview with Jadis Dumas, 7 Aug 2012. Skype. 
are trying to create television quality production with an open bias towards people's movements, so that we offer a real, high quality, produced alternative to both the public and the private sectors. It is very clear that the private and the public arms of the fourth estate are not going to give any sort of support or even equitable voice to the students and their objectives. But our mandate is different from the public or the private. We are not beholden to shareholders, profits, or the state. We are there to represent communities that otherwise lack representation or are misrepresented in the mainstream media ... We exist to give a platform to those voices - a high quality, well produced platform that can offer a challenge to the 24 hour production cycle of huge TV stations and the quality of footage they produce. Carrying a laptop or filming with a cellphone isn't going to cut it for the quality of production we want. Citizen produced media is very important and worthwhile, but we want to produce something different - a sustainable, high quality alternative - and for that we needed to invest in the technology. (Thorburn 2013b)

Together, the technology and volunteers of CUTV gave legitimacy to the project of the live stream broadcasts: the mobility afforded by the LiveU backpack and camera meant that the station could broadcast live from the midst of demos each night; the activist credentials and clear bias towards students opened the demonstrators up to the station. Thus the convergence of technology with human bodies created a moment wherein socially reproductive resistances - in this case modes of communicative social reproduction in line with the goals and aims of participatory journalism could emerge. Participatory journalism aims to provide insider perspectives on the struggle, thus helping marginalised communities "resist cultural domination and homogenisation;" creating and supporting "local, 'homegrown' media and content that better represents their interests" (Lievrouw 2011, 146). Such was the aim of CUTV, according to Marouf, who stated that the station existed to represent communities left out of mainstream or corporate media discourses, or not permitted to represent themselves (Thorburn 2013). CUTV's journalistic model developed the affective dimension of journalism, critiquing and opposing "the market-driven cynicism and detachment of the mainstream press" (Lievrouw 2011, 148).

Because CUTV developed bonds of trust with strikers and because journalists were movement participants themselves, they often possessed insider knowledge and were able to access spaces, places, and voices that mainstream and corporate media could not. This element of participatory journalism contributes to freer flows of information - as Lievrouw (2011) notes, breaking through the informational blockade often constructed by private media firms. Such far-reaching breakage of information blockades is only made possible through the advances in social media technologies in recent decades ${ }^{11}$ - social media emerged as an important source for the latest news and aided in keeping movement participants abreast of the latest developments throughout the 2011 cycle of struggles. As with other social media platforms CUTV's

\footnotetext{
${ }^{11}$ As noted in Chapter Two, Radio Alice was able to break through informational blockades by opening up phone lines to callers from the sites of struggle, but the reach of such free flowing information was limited by the broadcast range of the station.
} 
live stream used the same tools and sent information along the same globalised cybernetic flows that "transnational network capitalism" (Fuchs 2009) travels, while attempting to communicate in an oppositional and antagonistic mode. CUTV reappropriated the digital tools of social reproduction (social media) to create sites for autonomous self-representation and subject formation.

Against the standard definition of "participatory journalism," though, CUTV did not adhere to the "practices and values of professional journalism" (Lievrouw 2011, 148), such as objectivity, balanced reporting, and professionalism (Jeppesen 2012). Taking on the perspective of the students meant that CUTV was often unabashedly biased in their coverage. Laith Marouf, former Station Director and frequent camera operated stated explicitly that the "station favours the striking students and their supporters" and that if people want "the voice of the premier and the police and the university president amplified a thousand times"12 they can tune into mainstream media. In a workshop on "Autonomous Media" at the Montreal Anarchist Bookfair, Station Manager Laura Kneale discussed the importance of bias in CUTV's reporting, suggesting that CUTV's bias removes the veil of objectivity from mainstream media, and reveals the biases inherent in media forms owned by corporate or state entities (Jeppesen 2012). When CUTV presents the viewpoints and voices of students in their entirety the absence of these same voices from mainstream media becomes glaringly apparent. ${ }^{13}$ Kneale notes:

The live streaming is important for me because I see people having access to information about what is going on in the demonstration and why, I see people being represented as they are, not as caricatures. And when people see this, they begin to feel empowered by the media; it isn't focussed on criticisms, doesn't emphasize only the vandalism of les casseurs. Instead, I feel that CUTV's live streaming coverage really popularised the movement and it also forced the mainstream media to reciprocate, to improve their coverage. The mainstream media had to begin covering the strike, or else our bias would be the only one people had access to. (Thorburn 2013b)

This purposeful bias is an important, socially reproductive element of CUTV's live stream, and it is at least partially possible because of the immediacy of the technology. In the forthcoming section I will discuss what role the immediate - and thus marginally mediated - plays in the construction of autonomous social reproduction. The immediate is the intimate; minimally mediated at least insofar as that is possible when visual information flows through the networks and nodes of the Internet.

\section{Immediacy and the Live Stream's Socially Reproductive Moments}

In a capitalist framework, immediacy contributes to the affective modes of panic or anxiety, that which Berardi (2009) and the Institute for Precarious Consciousness (2014) refer to as the dominant affective mode of our time. Immediacy is now "laced with anxiety" (Institute for Precarious Consciousness 2014), a perpetual present in

\footnotetext{
12 Interview with Laith Marouf, 22 Jun 2012. Montreal, QC.

${ }^{13}$ In fact, any coverage of the strike - especially in English media - was for a long time absent in its entirety. It was with the live streaming of the movement and with the heating up of tensions between strikers, the state, and police that mainstream coverage began to appear.
} 
which all are commanded to communicate and be communicable. But from the perspective of the human-technological media merger - in the context of a massive strike of millennial postsecondary students - immediacy proffered through CUTV's live stream builds the affective bonds that respond to anxiety or panic, deepening capacities for an autonomous social reproduction. The exhortation to communicate and be communicable becomes, through the lens of CUTV, instead an invitation to self-representation and participation similar to the participatory democracy embodied in the physical assemblies.

Invoking an autonomous social reproduction through the immediacy of CUTV's live stream will be demonstrated in three main ways. First, that the immediacy allowed for the direct and minimally-mediated transmission of the feeling of protest. Second, the expressions of these feelings on the part of strikers, through the live stream and to viewers, allowed for self-representation from striking students. And finally, both the transmission of feeling and the self-representation of strikers both contribute to an urgency that encourages participation from viewers at home.

As Jeppesen (2012) pointed out, what was unusual about CUTV's broadcasts, in comparison to mainstream video reporting, was the powerful conveyance of the emotions of protest that the live stream was capable of. Because they were live, and because they were close to the movement themselves - and also because they were frequently the targets of police violence - CUTV volunteers often responded emotionally to the situations they found themselves in. The intentional bias of the station and the movement-basis of the volunteer demographic also contributed to the high levels of affect that flowed through CUTV's live stream. Because the volunteers placed themselves at the centre of protest, in the midst of striking students and in the face of police in riot gear, the video images transmitted were uniquely capable of creating and demonstrating the affective conditions of a demonstration - often the confusion, the fear, the anger. As CUTV volunteer Mikelai Cervera notes "it is hard not to be emotional in the spur of the moment, if you are being charged by the police, if you are being kettled, if you witness something upsetting, or if you are a victim yourself." 14

The rawness of CUTV's footage - because perpetually live and unedited - transmitted the urgency of the demonstration as reporters cried for help and stumbled around confused after being pepper-sprayed by police, ran in fear from fired sound cannons and stun grenades, or gasped audibly and yelled in rage at police violence inflicted upon their friends and comrades. While controversial for some,$^{15}$ the expression of open and honest emotions - the impacts of being in the midst of, and part of, demonstrations created a level of honesty and transparency in the live stream. This honesty was communicated to viewers and contributed to the creation of bonds of trust. As well, the live stream transmitted the urgency of the demonstrations, giving voice to the affective dimensions of protest in ways that other social media forms cannot quite articulate. Live video conveys so much more, and much more viscerally,

\footnotetext{
${ }^{14}$ Interview with Mikelai Cervera, 18 Jun 2012. Skype.

${ }^{15}$ Certainly there was dissent within the live stream teams about expressing certain levels of emotion, particularly anger. On one occasion, after being attacked by police from behind and pepper sprayed, several CUTV volunteers reacted angrily, screaming at a passing collection of riot police with epithets of "pigs!" and raising their middle fingers in the police's direction. Other members of the CUTV team were quick to admonish these actions saying that it made the station too overtly political and put the live stream team in danger of further police retaliation and attack. While emotions were demonstrated on camera regularly - and sometimes unintentionally, as is the nature of live video - it was not clear that all volunteers were entirely in favour of this.
} 
than other mainstream news coverage or even a Facebook post, Tweet, or YouTube uploads possibly can because it is ongoing, live, and raw. CUTV's live video stream incorporated viewers into the demonstrations, making them fee/ what participants felt, and in that making them participants themselves - slowly interpolating viewers into sympathisers and then actors.

But anger, fright, and rage were not the only emotions displayed through CUTV's live stream. As with the roving casseroles, live streaming the nightly marches also opened a window onto both the mundane moments of protest as well as the joyful ones. Marching for long evenings throughout Montreal could be devoid of the riotous cat-and-mouse game with the police, but the live video feed could then convey the conversations and friendships built through long collective night walks through the city's streets. The live stream could capture conversations amongst friends and was a space for demonstrators to come and share their own feelings and opinions. As well, the excitement of being engaged in acts of defiance and protest could be communicated through the live stream - both in the quiet moments and in the moments of action. The immediacy of the live stream conveyed to wide audiences the joy that Sterne (2012) and Barney (2012) found in voicing dissent collectively and building movements together, the emergence of a sociality without commodification. Moments captured by CUTV's live stream conveyed the temporary bubbles of joyous - as well as enraged - affect emerging throughout moments of protest. The stream captured the "outpouring of emotion and relief," and the "weighty sentimentality" (Sterne 2012, n.p.) that was enacted publicly each night in the roving demonstrations, and asserted both of the commonality of feeling and the commonality of the space the strike participants claimed. Through the live streaming video, strikers insisted on the space of the city as common, and made embodied "care" central to maintaining a collective ownership over this urban environment. In a letter to the editor of Quebec newspaper Le Devoir one writer noted that the being-together of protest was central to a sociality to come, and live video feeds of this emergent sociality was a central element of CUTV's socially reproductive capacity:

Now people greet and talk. Now neighbourhood meetings, discussions, vigils start up casually among neighbours on the steps and balconies of Montreal. The neighbourhood will be less and less alien. This is a true political victory!

We should repeat this friendly beating [the evocation of tapage doesn't quite work as well in English] possibly in other forms, until the land is occupied by neighbours who recognize one another, encounter one another each day by chance, and have known one another over the years. That is how we live in a place that is how we become citizens.

My heart swells with joy. ${ }^{16}$

In these moments of social movement resistance, social reproduction is reclaimed from the commodifying and securitising forces that capital seeks to impose upon it, and CUTV contributes to this reclamation through the diversity of affect the live stream was capable of displaying. Alongside rage, CUTV could clearly demonstrate "the camaraderie of intergenerational communities banging on pots and pans" and

16 The full text of the letter can be read on Le Devoir's website, available online here: http://www.ledevoir.com/politique/quebec/350721/victoire-collaterale Last accessed 5 Mar 2015. 
give voice to "the emotional impetus behind why people feel it is important to be in the streets, how people feel about austerity, and why they believe tuition should be free" (Jeppesen 2012, n.p.). Beyond simple binaries of joy and rage, CUTV's live stream could demonstrate the complexity of people's emotional engagement with protest, with movements, and with media. Action-driven emotions such as the tension and panic people feel when unintentionally trapped in a police kettle, or how temporarily disorienting tear gas or pepper spray attacks can be demonstrate "how traumatising certain interactions can be, particularly when police violence is experienced or witnessed" (Jeppesen 2012, n.p.). These affects are not as consistently and powerfully reproducible in mainstream media footage, nor in print or other social media venues. Live stream footage can, though, most accurately portray them.

The immediacy of the live stream also extended the ability of movement participants to engage in self-representation in the same honest, transparent, and affectively complex way to viewers. Both CUTV viewers and strike participants "felt really close to their media," as CUTV volunteer Jadis Dumas states, because of its unedited content. Viewers at home could "follow exactly what was going on in the streets" and people in the streets "knew that if they spoke to CUTV their words would be reproduced exactly." Much like the desire for self-representation and the refusal to accept distant leadership at play in the politics of the assembly movements, the desire for a media form that permitted self-representation and hence some autonomous subject formation was met with the CUTV live stream. Because of the commitment of the CUTV volunteers to deliver transparent demonstrations of anger, frustration, and confusion in protests, as well as joy, excitement and love, movement participants developed an overall sense of kinship and solidarity with the station, and viewers could find common ground with the demonstrators. At demonstrations people who "felt the urgency to speak their mind would come right up to us and say what they had to say" says Dumas, and people watching at home would receive this information without editing or mediation.

The immediacy of the CUTV video form also developed intimate relations through digital technologies between movement participants and viewers at home. This allowed overlapping between viewers and participants to develop. Viewers could began to feel connected to both the individuals they were seeing on their screens and the struggle they were a part of, because they were privy to the unedited reflections from participants and their often harrowing experiences of the street. This connection between the assembly, assemblages, and immediacy contributes to the minor current of assemblage politics; increasing participation and interpolating new subjects into strugglers in class-based movements. CUTV volunteer Jesse Freeston argued that the live stream actually encouraged active participation amongst those viewing the feed. ${ }^{17}$ Instead of defeat or paralysis - feelings he claims are common when watching distanced, biased corporate reporting, or in other forms of media produced at a remove from the action - the live stream encourages engagement and connection. Live streaming video shows "that not only does this movement exist, but it exists right now, it is happening right now" - its action is immediate, and therefore so too can be one's participation. This allows viewers to see that "not only are people not alone in thinking [that things aren't right and that education should be cheaper or free] but that there is a whole movement of people stepping up to the plate," and thus viewers can feel that their participation in the struggle is possible. The particular digital tools used in the Quebec Student Strike were a part of growing the minor current of the assembly, turning the immediacy of digital and social media from a force to

\footnotetext{
${ }^{17}$ Interview with Jesse Freeston, 17 Jun 2012. Montreal, QC.
} 
rend apart social relations to a force for the bonding of and intimacy between people. The live stream itself became a site of recuperated social reproduction.

In its role as participatory journalism and through its immediacy, CUTV's live streaming formed a complex human-digital merging that proved integral to contemporary assembly movements. Through the modems, wireless signals, information packets, and the live stream, CUTV's digital body created an electronic fabric onto which viewers could stitch themselves. In this, they became implicated in the demonstrations - the live stream provided a framework for viewers' own autonomous formation of ideas, identities, and subjectivities. This itself served as social reproduction mediated through a very technologically sophisticated medium. Viewers and participants alike - sometimes found in the same body - could develop more radical subjectivities, more radical politics, through seeing oneself and one's comrades honestly, transparently, and complexly displayed. This contrasts with the anxiety and panic that Berardi (2009) and the Institute for Precarious Consciousness (2014) claim is the primary, or even exclusive, outgrowth of pervasive digital media's immediacy. With CUTV's live stream, comes the solidarity, kinship, desire to communicate, and bonds of trust necessary for constituting a recuperated social reproduction in the realm of communication but also, importantly, in the realm of the concrete, the political, the lived.

Since 2012, newer, more portable, and more accessible live streaming technologies have become popularly available. Although research on new live streaming apps such as Meerkat and Periscope is scant, their use is important to consider both for what they offer to social reproduction in resistance movements, but also for how they may contribute to the re-insertion of socially reproductive processes in circuits of commodification and securitisation. In this brief final section I will discuss some of these new apps and how they are being used in different sites and by different actors.

\section{Technological Change and the Future of Live Streaming}

Since 2012, live streaming has remained an important element of "citizen journalism" and the recent introduction of live streaming mobile apps like Periscope, Meerkat, and Facebook Live have proliferated the quantity - if not the quality - of "citizen" and "independent" journalists, especially those covering moments of social and political unrest across North America. The emerging mobile technologies for live streamlining are powerful tools for creating immediate, intimate portraits of social movements as they unfold in real time across the globe. But without careful consideration and careful use, they threaten to become just another weapon adopted and utilised against movements by corporate journalists and even by police forces. It is precisely in the ways that make live streaming politically powerful for social movements that they serve to threaten the interests and aims of corporate media.

In the 2014 uprisings across the United States against police violence, for example, mainstream journalists for corporate news outlets made use of emerging platforms such as Periscope and Meerkat to expand the coverage brought to their audiences, providing a more "authentic" view of the protests. Antagonistic to the socially reproductive elements of immediacy made evident through the live stream, such corporate engagements with live streaming sought to control the messaging as best they could. In a blog post for the BBC's "College of Journalism" site, the two journalists note: "Of course streaming live meant any profane language being shouted could not be censored (you can only 'mute' the phone by holding your fingers against the microphone). This is perhaps where the second journalist, the producer so to speak, 
was helpful, because we could pre-interview people, making sure they were aware of the nature of the live broadcast." (Botti and Strasser 2015, n.p.).

At the same time, the expansion of live streaming capabilities through new technologies and platforms, Facebook Live in particular, has had radically accessible disparate, often distant and isolated movements and actors. A proliferation of live streamers, even when not affiliated with larger bodies or organisations like CUTV, can deepen socially reproductive solidarities across and between movements. Recent live video from individual citizen journalists uploaded to Facebook Live have mobilised support for the land defenders of the \#NoDAPL protests in Standing Rock, ND and water protectors occupying Muskrat Falls in Labrador, Canada. Bearing witness to both the violence of the state - in the case of \#NoDAPL - and the careful conversations of the water protectors - in the case of Muskrat Falls - was made possible through the live streaming video that have been present at both scenes.

It is the capacity of the live stream to expand the bonds of social reproduction that is so unsettling to the state, precisely because of the ways it inscribes viewers subjectively into the affective dimension of struggle. Because the mediation is so minimal, live stream footage uploaded and then archived via, for example, Facebook Live communicates the fear, the contemplation, the love, and the rage that are integral, embodied elements of social struggle.

In a highly technical, cybernetic environment the socially reproductive aspects of live streaming form part of the unfolding historical lineage of more analogue, embodied media activities, and older practices of film and video. These include such disparate activities as letter writing, pamphleteering, consciousness raising groups operating alongside the older media forms of guerrilla television, pirate radio, and radical film and documentary-making (Boyle 1992; Askanius 2014; Gregory 2010, for example). In fact many of the questions of surveillance, security, safety, and activism have already been considered by earlier generations of activists and scholars considering the role of technology in social movements (Gregory 2010; Gregory et al. 2005). But what live streaming in general - but CUTV's collective project in particular - offers us that is unique is strengthened insight into how we develop and recover alternative modes of subject constitution. And these alternative modes are made clear precisely through an understanding of social reproduction focussed directly on these technologies of mediation. Through live streaming we can understand how social movement actors navigate the conditions before them and put their politics into practice, while also bearing witness to the might an power of the state to oppose their collective actions.

To continue and even deepen the capacity for social reproduction within the practices of the live stream requires more than just access to technology but rather careful engagement with it. It requires imagining the technology as an element in the toolkit of social movements, but one which is ambivalent regarding outcomes. It must be used to advance the struggles around which social movements situate themselves and when it not longer serves those purposes live streaming can be - must be - put away to avoid its use as a weapon against those same movements and struggles.

\section{References}

Andrejevic, Mark. 2011. "Surveillance and Alienation in the Online Economy." Surveillance and Society 8(3).

Askanius, Tina. 2014. "Video for Change." In Tufte, Thomas, Karin Gwinn Wilkins, and Rafael Obregon (eds). Handbook on Development Communication and Social Change. Wiley Blackwell. 453-470. 
Barney, Darin. 2012. "Reflections on the 2012 Quebec Student Movement." Lecture given at Communication Studies Speakers Series, School of Journalism \& Communication. Carleton University, Ottawa, Ontario. 16 November. Available online at http://darinbarneyresearch.mcgill.ca/Work/Reflections on the 2012 Quebec Student St rike.pdf. Accessed 24 February 2015.

Berardi, Franco "Bifo." 2009. The Soul At Work: From Alienation to Autonomy. Los Angeles: Semiotext(e).

Bezanson, Kate and Meg Luxton. 2006. Social Reproduction: Feminist Political Economy Challenges Neoliberalism. Montreal: McGill Queen's University Press.

Boler, Megan, Averie Macdonald, Christina Nitsou, and Anne Harris. 2014. "Connective Labour and Social Media: Women's Roles in the Leaderless Occupy Movement." Convergence 20(4): 438-460.

Botti, David and Franz Strasser. 2015. "Live-streaming the Ferguson Protests: We had to give Meerkat a try." BBC Academy. 17 March. Available online at: http://www.bbc.co.uk/blogs/collegeofjournalism/entries/40d417e6-1c21-449f-a2f3e299aa221b6d. Accessed 27 June 2016.

Boyle, Deirdre. 1992. "From Portapak to Camcorder: A Brief History of Guerrilla Television." Journal of Film and Video 44: 67-79.

Brown, Gareth, Emma Dowling, David Harvie, and Kier Milburn. 2013. "Careless Talk: Social Reproduction and the Fault Lines of the Crisis in the United Kingdom." Social Justice 39(1).

Chen, Adrian. 2014. "Is Livestreaming the Future of Media, or the Future of Activism?" New York Magazine. 7 December. Available online at: http://nymag.com/daily/intelligencer/2014/12/livestreaming-the-future-of-media-oractivism.html. Accessed 27 June 2016.

Cockburn, Patrick. 2010. "Embedded Journalism: A Distorted View of War." The Independent. November 27. Accessed 29 October 2016.

http://www.independent.co.uk/news/media/opinion/embedded-journalism-a-distorted-viewof-war-2141072.html

Dalla Costa, Mariarosa and Selma James. 1973. The Power of Women and the Subversion of the Community. Bristol: Falling Wall Press.

Dyer-Witheford, Nick. 2015. Cyber-Proletariat: Global Labour in the Digital Vortex. London: Pluto Press.

Ezquerra, Sandra. 2012. "Feminist Practice in the 15M Movement: Progress and Outstanding Issues." Open Democracy. 12 July. Available online at: https://www.opendemocracy.net/sandra-ezquerra/feminist-practice-in-15-m\#footnote2. Accessed 17 February 2015.

Federici, Silvia. 2012. Revolution at Point Zero: Housework, Reproduction, and Feminist Struggle. Oakland: PM Press.

Federici, Silvia. 2004. The Caliban and the Witch: Women, the Body, and Primitive Accumulation. Brooklyn: Autonomedia.

Fortunati, Leopoldina. 1996. The Arcane of Reproduction: Housework, Prostitution, Labour, and Capital. Brooklyn: Autonomedia.

Fuchs, Christian. 2009. "A Contribution to the Critique of Political Economy of Transnational Network Capitalism." Rethinking Marxism 21(3).

Gerbaudo, Paolo. 2012. Tweets and the Streets: Social Media and Contemporary Activism. London. Pluto Press.

Gregory, Sam. 2010. "Cameras Everywhere: Ubiquitous Video Documentation of Human Rights, New Forms of Video Activism, and Consideration of Safety, Security, Dignity, and Consent." Journal of Human Rights Practice 2(2): 191-207.

Gregory, Sam, Gillian Caldwell, Ronit Avni, and Thomas Harding (eds). 2005. Video for Change: A Guide for Advocacy and Activism. London: Pluto Press. 
Haiven, Max. 2011. "Feminism, Finance, and the Future of Occupy: An Interview with Silvia Federici." Libcom.org. https://libcom.org/library/feminism-finance-future-occupy-interviewsilvia-federici. Accessed 29 October 2016.

Herman, Edward S. and Noam Chomsky. 1988. Manufacturing Consent: The Political Economy of Mass Media . New York: Pantheon Books.

Herman, Edward S. 1996. "The Propaganda Model Revisited." Monthly Review. July. Available online at: http://www.chomsky.info/onchomsky/199607--.htm. Accessed 9 March 2015.

Herrera, Linda. 2014. Revolution in the Age of Social Media: The Egyptian Popular Insurrection and the Internet. New York: Verso Books.

Institute for Precarious Consciousness. 2014. "Anxiety, Affective Struggle, and Precarity Consciousness Raising." Interface: A Journal for and about Social Movements. 6(2): 271300.

Jeppesen, Sandra. 2012. "Livestreaming on CUTV: 'Emboldened riot culture' of Student Strike." Wi: Journal of Mobile Media 6(2).

Jung, Alex E. 2014. "Wages for Facebook." Dissent Magazine. https://www.dissentmagazine.org/article/wages-for-facebook. Accessed 29 October 2016.

Lievrouw, Leah A. 2011. Alternative and Activist New Media. Malden, MA: Polity Press.

Marx, Karl. 1978. Capital: A Critique of Political Economy Volume 2. New York: Penguin Books.

Marx, Leo. 2010. "Technology: The Emergence of a Hazardous Concept." Technology and Culture. 51(3): 561-577.

Myers, Steven Lee. 2010. "Embedistan: Embedding in Iraq During Invasion and Draw Down." New York Times. August 20. Accessed 29 October 2016.

http://atwar.blogs.nytimes.com/2010/08/20/embedistan-embedding-in-iraq-during-theinvasion-and-the-drawdown/

Sterne, Jonathan. 2012. "Printemps érable: Quebec's Maple Spring." Theory and Event 15:3.

Thorburn, Elise. 2013a. "Social Media, Subjectivity, and Surveillance: Moving on From Occupy, the Rise of Live Streaming Video." Communication and Critical/Cultural Studies 11(1): 52-63.

Thorburn, Elise. 2013b. "Squarely in the Red: Dispatches from the Quebec Student Strike" in Upping the Anti: A Journal of Theory and Action No. 14.

Thorburn, Elise. 2016. "Networked Social Reproduction: Crises in the Integrated Circuit." tripleC: Communication, Capitalism \& Critique. Open Access Journal for a Global Sustainable Information Society 14(2): 380-396.

Vischmidt, Marina. 2013. "Permanent Reproductive Crisis: An Interview with Silvia Federici." Mute Magazine. http://www.metamute.org/editorial/articles/permanent-reproductive-crisisinterview-silvia-federici. Accessed 29 October 2016.

Vogel, Lise. 2014 (1984). Marxism and the Oppression of Women. Chicago: Haymarket Books.

\section{About the Author}

\section{Elise Thorburn}

Elise Thorburn is an Adjunct Professor of Sociology at Brock University and a Postdoctoral Fellow with the On the Move Partnership at Memorial University of Newfoundland. With On the Move she investigates the use of algorithmic shift scheduling software in low-wage work environments, particularly those with extended commutes. She is also the Principle Investigator on a SSHRC Insight Development Grant-funded project entitled "Between the Office and the Prison Yard: Mobile Monitoring of Social Life" which examines the genealogy and circulation of emerging mobile surveillance devices across a variety of institutional settings. Specifically she is looking at the increasing movement of monitoring technology from prisons into immigration detention, elder-care facilities, and corporate and extractive industries, creating what she calls an expanded "carceral infrastructure" of capital and the state. 